\title{
Increasing Cultural Sensitivity Through Traditional Methodology And Via A Simulation Enhancement
}

Michael S. Munro, (Email: carointl@gate.net), Florida International University

\begin{abstract}
Globalization of business and the breakdown of national frontiers, particularly in services industries, has been a highlight of the beginning of the $21^{\text {st }}$ Century. Explosively growing economic activity in previously "developing" regions such as India and China can be linked to acceptance and incorporation of foreign ideas and influences. In contrast, economic stagnation continues to persist in areas where reluctance to adopt change and support for authoritarianism and tradition prevail. These current trends underscore the importance of preparing our future managers in cultural awareness and sensitivity. This study seeks to measure if cultural sensitivity can be increased through traditional academic methodology and, secondly, consider if cultural sensitivity can be further enhanced via a cultural simulation (of attempting to achieve goals when encountering a foreign culture).
\end{abstract}

\section{INTRODUCTION}

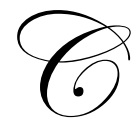

ultural differences are readily apparent in comparing international markets and it is considered important by a great variety of academic disciplines ranging from historians, psychologists, political scientists and economists. Cultural norms and practices are those shared beliefs, customs, and traditions that a group of people learned from their exposure to parents, teachers, leaders, and peers during their formative years.

Teaching cross cultural comparisons often begins with comparing similarities and dissimilarities between a given culture (e.g. your own) and a foreign (host) culture, which is often regional rather than national. One of the most basic points of comparison is the distinction between high context and low context cultures ${ }^{1}$. High context cultures such as Japanese, Arabic and Latin American, rely heavily on the context of a message (i.e. the relationship between sender and receiver, gender, age, status) and also the time and place of the message. Low-context cultures place greater importance to exactly what is said or written. Examples of low context cultures are the Swiss, Germans, and North Americans. The sequence and length of negotiations, the relative importance of contracts, the value of time, etc. have major differences between low and high context cultures.

One of the major efforts to codify these cultural differences was the extensive study of I.B.M. employees by Geert Hofstede $^{2}$ who mapped various dimensions in 1980. Hofstede labeled these as power distance, feminine masculine, uncertainty avoidance, and individualism - collectivism. In 1988, Hofstede and Michael H. Bond ${ }^{3}$ added the Long Term Orientation versus Short Term Orientation. Others have looked to the hierarchical values of a culture such as the work done by Abraham Maslow ${ }^{4}$ covering the United States wherein he concludes that needs at a definite level must be satisfied in order for higher-order needs to appear, beginning with physiological needs and progressing to safety and subsequent by the social needs, esteem and finally to self-actualization. Maslow's work in 1954 appears to generalize this theory throughout the world, but Mendenhall ${ }^{5}$, et al. (1955) found that Maslow's cross-cultural applicability is apparently not universal. This review found seven studies supporting cross cultural applicability, but these gave only partial support while ten studies concluded that Maslow's theory was not applicable across cultures. Belk $^{6}$ et al. (1997) concluded consumer desires, rather than satisfaction of Maslow's need levels, may be a more useful concept for cross cultural consumer behavior. This work supports a conclusion that needs and their link to satisfaction are also culture determined. 


\section{CULTURE AND ECONOMIC GROWTH}

Focusing on culture as it might impact economic power and the creation of wealth, David Landes ${ }^{7}$ asserts that although climate, natural resources, and geography play a role in industrialization, one key factor in industrialization is its cultural endowments and specifically values of hard work, honesty, thrift, patience, and tenacity. Landes specifically identifies the degree a society is open to change, new technology and gender equality, rather than historical legacy and vestiges of colonialism.

In Thomas Friedman's "The World is Flat" ${ }^{8}$ he finds two dimensions of culture particularly relevant to economic growth. One, he describes as how "outward" a culture is (i.e., to what extent is a culture open to foreign influences and ideas). He cites the other dimension as how "inward" a culture is (i.e. a sense of national solidarity and focus on development) and the concern with the economic welfare of the general population by the cultures' leadership.

Friedman argues that the more a culture absorbs foreign ideas and successful foreign practices into its own traditions, the greater advantage that culture will have in economic development. The current explosive economics growth in India and China he attributes to these cultural attributes. The opposite example Friedman cited, is the lack of growth in the Arab-Muslim world where there is strict reluctance to embrace change and a zealous desire to impose authoritarianism and return to the structures of the past. Specifically, this includes constraints on women and the condemnation of foreign ideas and rejection of non-believers of a radical version of the Koran.

\section{TEACHING CULTURAL SENSITIVITY}

If there is a link between a cultural openness and awareness and economic progress for the population, it is clear that developing cultural sensitivity is an important task for our educators. An obvious place to start is in our business schools and particularly those dealing with International Studies and Globalization.

To this end, this study attempts to measure changes in cultural sensitivity before and after an exposure to cultural differences. A change in attitudes might provide an insight into the ability to persuade students to be more tolerant and accepting of cultural differences.

The exercise was extended beyond the traditional exposure and understanding of cultural differences. One test group was additionally exposed to a simulation of a foreign culture to attempt to measure the difference between traditional academic approaches to the study of culture and the additional experience of being faced with a cultural environment, not your own, in a simulation.

\section{SIMULATION TEST}

The specific simulation tested was originally written in 1984 by Sivasailam Thiagarajan in an unpublished paper called "BARNGA: A Flexim on Cultural Clashes". In 1990, Barbara Steinwachs worked with Sietar International to produce an updated manual". The simulation is done through a simple card game and it "simulates the experience of encountering people from other cultures and discovering they are operating under different rules" ${ }^{10}$. In the process of moving toward goals in this environment of ambiguity and communication barriers, the participant must reconcile the differences in the cross cultural environment. In other words, Barnga puts participants in the shock of realizing that while there are many similarities; people from other cultures have important differences in the way they do things.

This study seeks to measure the impact of standard classroom exposure to cultural differences and also seeks to determine if an addition of the above simulation exposure would enhance the sensitivity to cultural differences. Both test groups were measured by the size of the shift between the period before any class exposure to cultural differences and after the cultural exposure. 


\section{OPINION SURVEY}

The measurement tool used was the respondents' relative agreement or disagreement on ten statements about cultural differences. These ten statements, which reflect attitudes generally intolerant and lacking in strong cultural sensitivity, were asked in pre and post cultural sensitivity education. The respondent was asked to indicate agreement - disagreement on a 5 point Likert scale. One point was given to strongly agree, two points for agree, three for neutral, four for disagree and five for strongly disagree. Thus, the higher scores indicate more cultural sensitivity and the lower scores less cultural tolerance.

The pre study consisted of 70 respondents in the test group and 40 in the control group. It should be noted that the source of the sample was relatively high in foreign born content reflecting the student body at Florida International University and one might speculate that the foreign born respondents might be more culturally sensitive. However, foreign born average scores were slightly lower than USA born respondents in both test (2.59 foreign vs. 2.76 USA) and control (2.32 Foreign vs. 2.42 USA). This would be consistent with the theory that exposure to the first foreign culture tends to reduce the sensitivity and acceptance through an entrenchment in one's native culture; and, that only through exposure to second and future foreign cultures could result in a more complete cultural appreciation and acceptance.

Pre-Cultural Awareness Exposure

\begin{tabular}{|c|c|c|c|c|c|}
\hline & \multicolumn{2}{|c|}{$\begin{array}{c}\text { Basic Exposure Group } \\
\mathrm{N}=\mathbf{4 0}\end{array}$} & \multicolumn{2}{|c|}{$\begin{array}{c}\text { Simulation Group } \\
(\mathbf{N}=\mathbf{7 0})\end{array}$} \\
\hline & & $\begin{array}{c}\text { USA Origin } \\
\text { Foreign Origin }\end{array}$ & $\begin{array}{l}19 \\
21\end{array}$ & $\begin{array}{c}\text { USA Origin } \\
\text { Foreign Origin }\end{array}$ & $\begin{array}{l}24 \\
46\end{array}$ \\
\hline \multicolumn{2}{|r|}{ Questions } & Score & & Score & \\
\hline 1. & Some cultures are superior to others & 3.6 & Slightly disagree & 3.9 & Disagree \\
\hline 2. & $\begin{array}{l}\text { In relation to international business, } \\
\text { it is very important to get agreements } \\
\text { in writing. }\end{array}$ & 1.4 & $\begin{array}{l}\text { Fairly strong } \\
\text { agreement }\end{array}$ & 1.5 & $\begin{array}{l}\text { Fairly strong } \\
\text { agreement }\end{array}$ \\
\hline 3. & $\begin{array}{l}\text { In negotiations, it is important to get } \\
\text { on a first name basis as soon as } \\
\text { possible. }\end{array}$ & 2.6 & Neutral & 2.9 & Neutral \\
\hline 4. & $\begin{array}{l}\text { In international business, individual } \\
\text { achievement should always be } \\
\text { recognized and rewarded. }\end{array}$ & 2.4 & Neutral & 2.9 & Neutral \\
\hline 5. & $\begin{array}{l}\text { Harmonious groups always produce } \\
\text { better results. }\end{array}$ & 2.2 & Agree & 2.1 & Agree \\
\hline 6. & $\begin{array}{l}\text { Non verbal communication is second } \\
\text { in importance to verbal } \\
\text { communication. }\end{array}$ & 3,4 & Neutral & 3.1 & Neutral \\
\hline 7. & $\begin{array}{l}\text { Gender roles need to be suppressed } \\
\text { to bolster democratic ideals. }\end{array}$ & 2.6 & Neutral & 3.0 & Neutral \\
\hline 8. & $\begin{array}{l}\text { Religion needs to be set aside to } \\
\text { achieve international business } \\
\text { success. }\end{array}$ & 2.7 & Neutral & 3.0 & Neutral \\
\hline 9. & $\begin{array}{l}\text { Being punctual in appointments and } \\
\text { other business contacts will enhance } \\
\text { business prospects. }\end{array}$ & 1.3 & $\begin{array}{l}\text { Fairly strong } \\
\text { agreement }\end{array}$ & 1.8 & $\begin{array}{l}\text { Fairly strong } \\
\text { agreement }\end{array}$ \\
\hline \multirow[t]{2}{*}{10.} & $\begin{array}{l}\text { When in doubt, refer to your own } \\
\text { basic ethics. }\end{array}$ & 2.2 & Agree & 2.3 & Agree \\
\hline & Average of 10 questions & 2.37 & & 2.65 & \\
\hline
\end{tabular}


There was wide disagreement by respondents on Question \#1 asserting there is a superiority of some cultures. There was general agreement that "getting it in writing" is important, that harmonious groups produce better results and being punctual enhances business prospects. The respondents agreed that "self reference criteria"11 was a reliable practice. This last measurement is widely recognized by international experts as being detrimental to international decision making. ${ }^{11}$

Pre vs. Post Basic Exposure Group

Traditional Exposure To Cultural Differences

\begin{tabular}{|c|c|c|c|c|c|}
\hline & \multicolumn{2}{|c|}{$\begin{array}{r}\text { Pre } \\
\mathrm{N}=40\end{array}$} & \multicolumn{2}{|c|}{$\begin{array}{c}\text { Post } \\
(\mathrm{N}=56) \\
\end{array}$} \\
\hline & & $\begin{array}{l}\text { USA Origin } \\
\text { Foreign Origin }\end{array}$ & $\begin{array}{l}19 \\
21\end{array}$ & $\begin{array}{l}\text { USA Origin } \\
\text { Foreign Origin }\end{array}$ & $\begin{array}{l}24 \\
32\end{array}$ \\
\hline \multicolumn{2}{|r|}{ Questions } & Score & & Score & \\
\hline 1. & Some cultures are superior to others & 3.6 & Slightly disagree & 3.4 & Neutral \\
\hline 2. & $\begin{array}{l}\text { In relation to international business, } \\
\text { it is very important to get } \\
\text { agreements in writing. }\end{array}$ & 1.4 & $\begin{array}{l}\text { Fairly strong } \\
\text { agreement }\end{array}$ & 1.8 & $\begin{array}{l}\text { Fairly strong } \\
\text { agreement }\end{array}$ \\
\hline 3. & $\begin{array}{l}\text { In negotiations, it is important to get } \\
\text { on a first name basis as soon as } \\
\text { possible. }\end{array}$ & 2.6 & Neutral & 2.6 & Neutral \\
\hline 4. & $\begin{array}{l}\text { In international business, individual } \\
\text { achievement should always be } \\
\text { recognized and rewarded. }\end{array}$ & 2.4 & Neutral & 2.5 & Neutral \\
\hline 5. & $\begin{array}{l}\text { Harmonious groups always produce } \\
\text { better results. }\end{array}$ & 2.2 & Agree & 2.4 & Agree \\
\hline 6. & $\begin{array}{l}\text { Non verbal communication is second } \\
\text { in importance to verbal } \\
\text { communication. }\end{array}$ & 3,4 & Neutral & 3.2 & Neutral \\
\hline 7. & $\begin{array}{l}\text { Gender roles need to be suppressed } \\
\text { to bolster democratic ideals. }\end{array}$ & 2.6 & Neutral & 2.9 & Neutral \\
\hline 8. & $\begin{array}{l}\text { Religion needs to be set aside to } \\
\text { achieve international business } \\
\text { success. }\end{array}$ & 2.7 & Neutral & 2.7 & Neutral \\
\hline 9. & $\begin{array}{l}\text { Being punctual in appointments and } \\
\text { other business contacts will enhance } \\
\text { business prospects. }\end{array}$ & 1.3 & $\begin{array}{l}\text { Fairly strong } \\
\text { agreement }\end{array}$ & 1.8 & Agree \\
\hline 10. & $\begin{array}{l}\text { When in doubt, refer to your own } \\
\text { basic ethics. }\end{array}$ & 2.2 & Agree & 2.4 & Agree \\
\hline & Average of 10 questions & 2.37 & & 2.57 & $+8.4 \%$ \\
\hline
\end{tabular}

The group receiving basic exposure to cultural awareness and sensitivity through traditional classroom methodology in sessions covering about three hours showed a $8.4 \%$ increase in their sensitivity attitudes measured by the 10 question survey of cultural attitudes. The only specific areas with notable shifts were a $12 \%$ decrease in agreement with the importance of being punctual in business appointments, a $10 \%$ decrease in agreement with the statement on the importance of getting agreements in writing and a 7.5\% decrease in agreement with the statement that gender roles need to be suppressed. In general, we can conclude that about 3 hours of exposure to cultural differences can, at least temporarily, modestly shift attitudes toward being more cultural sensitive. 
Pre vs. Post Simulation Enhanced Group

Both Basic Exposure To Cultural Differences Plus A Simulation Of Being Faced With A Foreign Cultural Environment

\begin{tabular}{|c|c|c|c|c|c|}
\hline & \multicolumn{2}{|c|}{$\begin{array}{c}\text { Pre-Study } \\
\text { N=70 }\end{array}$} & \multicolumn{2}{|c|}{$\begin{array}{c}\text { Post-Study } \\
(\mathbf{N}=70)\end{array}$} \\
\hline & & $\begin{array}{l}\text { USA Origin } \\
\text { Foreign Origin }\end{array}$ & $\begin{array}{l}24 \\
46\end{array}$ & $\begin{array}{l}\text { USA Origin } \\
\text { Foreign Origin }\end{array}$ & $\begin{array}{l}25 \\
45\end{array}$ \\
\hline & Questions & Score & & Score & \\
\hline 1. & Some cultures are superior to others & 3.9 & Disagree & 4.2 & Disagree \\
\hline 2. & $\begin{array}{l}\text { In relation to international business, it } \\
\text { is very important to get agreements in } \\
\text { writing. }\end{array}$ & 1.5 & $\begin{array}{c}\text { Fairly strong } \\
\text { agreement }\end{array}$ & 2.4 & Slightly agree \\
\hline 3. & $\begin{array}{l}\text { In negotiations, it is important to get } \\
\text { on a first name basis as soon as } \\
\text { possible. }\end{array}$ & 2.9 & Neutral & 3.0 & Neutral \\
\hline 4. & $\begin{array}{l}\text { In international business, individual } \\
\text { achievement should always be } \\
\text { recognized and rewarded. }\end{array}$ & 2.9 & Neutral & 3.0 & Neutral \\
\hline 5. & $\begin{array}{l}\text { Harmonious groups always produce } \\
\text { better results. }\end{array}$ & 2.1 & Agree & 2.2 & Agree \\
\hline 6. & $\begin{array}{l}\text { Non verbal communication is second } \\
\text { in importance to verbal } \\
\text { communication. }\end{array}$ & 3.1 & Neutral & 3.1 & Neutral \\
\hline 7. & $\begin{array}{l}\text { Gender roles need to be suppressed to } \\
\text { bolster democratic ideals. }\end{array}$ & 3.0 & Neutral & 3.3 & Neutral \\
\hline 8. & $\begin{array}{l}\text { Religion needs to be set aside to } \\
\text { achieve international business success. }\end{array}$ & 3.0 & Neutral & 3.2 & Neutral \\
\hline 9. & $\begin{array}{l}\text { Being punctual in appointments and } \\
\text { other business contacts will enhance } \\
\text { business prospects. }\end{array}$ & 1.8 & $\begin{array}{l}\text { Fairly strong } \\
\text { agreement }\end{array}$ & 2.4 & Agree \\
\hline 10. & $\begin{array}{l}\text { When in doubt, refer to your own } \\
\text { basic ethics. }\end{array}$ & 2.3 & Agree & 2.7 & $\begin{array}{l}\text { Approaching } \\
\text { neutral }\end{array}$ \\
\hline & Average of 10 questions & 2.65 & Versus & 2.95 & $+11.3 \%$ \\
\hline
\end{tabular}

The second test group received the same exposure to cultural differences as the first group but was additionally exposed to a simulation of being placed in a foreign culture they did not understand and encouraged to work toward established objectives. Overall, this test group scored an $11.3 \%$ increase in the average of 10 questions related to cultural sensitivity. On specific questions, there was a $22 \%$ decrease in agreement on the importance of getting international agreements in writing, a 15\% decrease in agreement with the importance of being punctual for business appointments, a 10\% decrease in agreement with "When in doubt, refer to your own basic ethics", and a $7.5 \%$ decrease in the statement that "Gender roles need to be suppressed to bolster democratic ideals".

The simulation addition was directionally stronger $(+11.3 \%$ vs. $8.4 \%)$ than the traditional academic exposure and the number of questions where a notable shift in disagreement was observed increased from 3 to 4 and the extra question "Some cultures are superior to others" showed a 7.5\% increase in the simulation based group and a $5 \%$ decrease in the group exposed to the basic academic instruction in cultural awareness and sensitivity.

\section{CONCLUSIONS}

1. The small scale tests appear to indicate that cultural awareness and sensitivity can be increased through exposure to cultural differences.

2. There appears to be value in adding a simulation of exposure to a foreign culture to deepen the degree of cultural sensitivity.

3. There seems to be a slight entrenchment in one's own culture when moved the first time into a foreign culture. 


\section{REFERENCES}

1. $\quad$ Edward T. Mall, Betyon Culture (New York: Doubleday, (1977).

2. Hofstede, Geert, Culture's Consequences: International differences in work-related values, Sage: Beverly Hills, CA (1980).

3. Hofstede, Geert and Bond, Michael H., The Confucius Connection Organizational Dynamics, 16 Spring 1988 pp. 4-21.

4. Maslow, Abraham H., Motivation and Personality, Harper and Row: New York, (1954).

5. Mendenhall, Mark, Betty Jane Punnett, and David Ricks (1995), Global Management, Blackwell: Cambridge, MA.

6. Belk, Russell W., Guliz Ger, and Soren Askegaard (1997), Consumer desires in three cultures: Results from progressive research, Advances in consumer research, Vol. 24 Association for consumer Research: Provo, UT. pp. 24-27.

7. $\quad$ Landes, David, The Wealth and Power of Nations, Little, Brown \& Co. London, 1998.

8. $\quad$ Friedman, Thomas, Farrar Straus, and Giroux, The World is Flat, 2005 pg. 324-325.

9. Thiagarajan, Silvasailam, Sietar International Publication 1990, 1994. For information, contact Intercultural Press, Inc. Yarmouth, Maine.

10. Ibid, cover page.

11. Lee, J. A., Self reference criteria was originally coined Cultural Analysis in Overseas Operations, Harvard Business Review (March-April 1966): 106-114.

12. Lee, James A. Cultural Analysis in Overseas Operations, Harvard Business Review, (Mar-April 1966) pp. 106-114; Dana-Nicoleta Lascu, International Marketing, Atomic Dog Publishing 2003 pg. 13-14 and 106107; Cateora \& Grahams, International Marketing, McGraw Hill, 2005 pg. 15-17. 